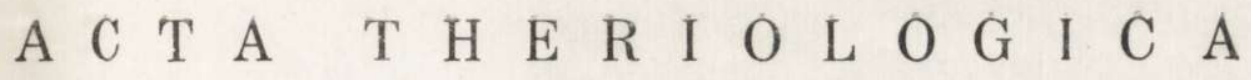 \\ VOL. X, 1: 1-10.

\author{
Gabriela B U J A L S K A, Krystyna C A B O Ń - R A C Z Y Ń S K A \\ \& Jan R A C Z Y Ń S I
}

\section{Studies on the European Hare. VI. Comparison of Difierent Criteria of Age}

[With 1 Fig. \& 3 Tables]

\begin{abstract}
Considerable differences are found in the estimation of hares' age by S:r o h's method, using the techniques consisting in palpating through the skin and visual observation of the epiphysial thickening. Errors made may be dependent on the person conducting the examination. The occurrence of divergences between identifications of age by methods based on growth changes (degree of formation of the epiphysial cartilage of the ulaa, ossification of the skull and pelvis sutures) were considered as proof of the uneven rate of ossification of different parts of the skeleton. Taking into account the ease with which S $\mathrm{tr}$ o h's method can be applied to mass examination of hares it was held to be suitable to rely on visual estimation of age, after slitting the skin on the forearm.
\end{abstract}

\section{INTRODUCTION}

The establishment of the exact age of hares is of fundamental importance to an analysis of the age structure of a population and an estimate of the birthrate, and in consecuence to forecasting shoots.

The age of hares is most of ten defined on the basis of the disappearance of the epiphysial cartilage on the distal part of the ulna ( $\mathrm{t} \mathrm{roh}, 1931)$. This method is known as "Stroh's method" (P i e c k, 1956). American research workers most of ten make use for this purpose of the ossification process of the proximal epiphysis of the humerus (L e chleitn er, 1959). The weight of the eye lens has recently also been used as an indicator of age ( $\mathrm{L} \mathrm{or} \mathrm{d}, 1959 ; \mathrm{R} \mathrm{i} \mathrm{e} \mathrm{c} \mathrm{k,} \mathrm{1962).} \mathrm{Of} \mathrm{the} \mathrm{methods} \mathrm{referred} \mathrm{to,}$ only Stroh's method is used under field conditions, as the others involve the necessity for laboratory work on the material. It is also possible to create criteria for segregation according to age on the basis of anatomical examination of growth changes in various elements of the skeleton. In our laboratory the age of hares was defined cr. the basis of the degree of obliteration of certain skull sutures ( $\mathrm{Ca}$ bo n $-\mathrm{R}$ ac zyńska, 1964) and growth changes in the pelvis (B u ja is ka, 1964). In our inve- 
stigations we had at our disposal an extensive series of material from the full yearly cycle, together with certain supplementary data (date of shooting, body weight, state of sexual activity), which made it possible to establish the absolute age of young hares.

The aim of present study is to compare the generally used field method (S tro h's method) with certain laboratory methods for establishing the age of hares.

\section{MATERIAL AND METHODS}

A total of 150 hares were used for the investigations, selected from a large series representing three age groups (described below), distinguished by $\mathrm{Str}$ o h's method, i.e. by palpation through the skin. Each of the groups distinguished consisted of 50 individuals. The hares came from one shooting district in the Poznan province and were obtained during the period from January 21st to February 2nd, 1963. Preparations were made of the eye lens, skull, pelvis and the skeleton of the brachial region within two to three days after the animal had been killed. The lenses were prepared from fresh material, and after cleaning were dried at a temperature of $40^{\circ} \mathrm{C}$, then weighed on an analytical balance with accuracy to $1 \mathrm{mg}$. Lenses were obtained from a total of 82 hares. The skulls and pelvises and the brachial skeleton were cleaned from muscles after boiling, then bleached with hydrogen peroxide. Measurements of the size of the epiphysial thickening were made on the ulnar bone, with a technical sliding scale, at the maximum breadth of the thickening in the plane vertical to the long axis of the forearm.

The age of the hares was defined by means of 5 methods, the material always being divided into three age groups.

1. S tro h's method - consisting in feeling the degree of formation of the epiphysial thickening through the skin. Identification was carried out by a qualified game expert, classifying the hares into three groups:

$A$ - containing individuals in which the epiphysial thickening was clearly palpable,

$B$ - containing individuals in which the thickening was only faintly perceptible, in process of disappearance,

C - containing individuals in which no thickening could be felt.

2. S t r o h's "visual" method based on visual estimation of the degree of formation of the thickening and occurrence of the epiphysial cartilage on the ulna. Here again the material was divided into three groups:

A - including specimens with a distinct insertion of epiphysial cartilage, visible between the strongly thickened parts of the shaft and the epiphyses of the ulna. In addition the occurrence was observed in this group of diaphysis and distinct tubercula on the distal part of the radius.

$B$ - specimens in which the epiphysial cartilage was only faintly visible, thickening markedly smaller.

C - specimens with complete disappearance of diaphysis and epiphysial line and formation of bone fusion. In the place in which the shaft had 
fused with the base a slight thickening of the ulna sometimes remains (Fig. 1).

The groups distinguished in this way should correspond, in our opinion, to the groups distinguished on the basis of the same character by palpating through the skin.

3. and 4. Methods based on the changes taking place with age in the skull and pelvis, described in the studies by Cabon - Raczynska (1964) and B u ja ls ka (1964). These methods make it possible to segre-
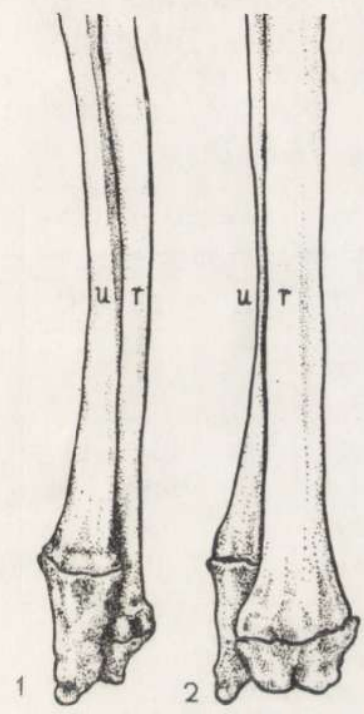

A
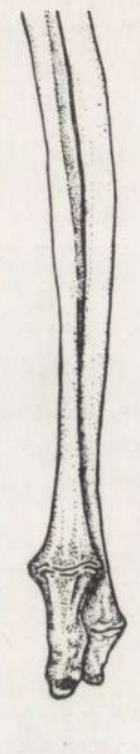
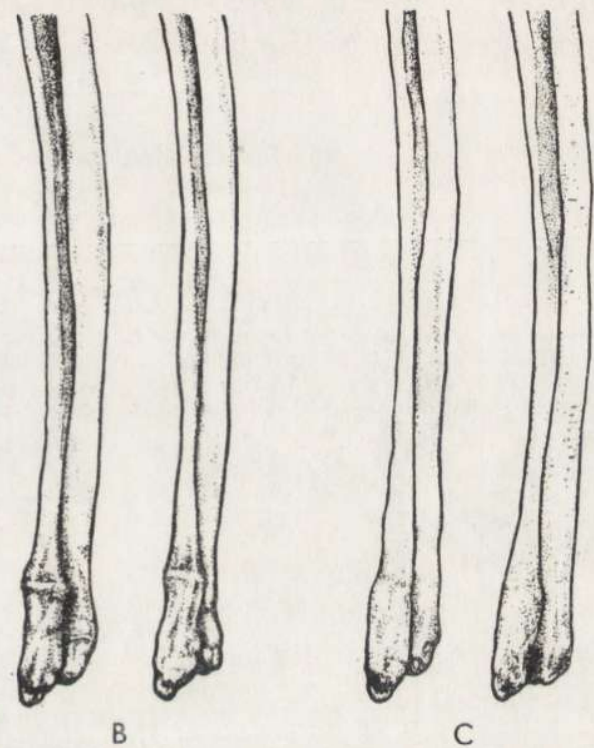

Fig. 1. Changes in the epiphysial thickening of the ulna in succesive age groups. A, B, C - age classes. 1. Viewed from the lateral side. 2. Viewed from in front. $\mathrm{u}$ - Ulna, $\mathrm{r}$ - Radius.

gate the material into a uniform number of age groups, to which the above authors attribute the same absolue age:

$A-$ (corresponds to age class $I$ in the studies referred to above) includes hares from $6-8$ months old,

$B$ - (corresponds to age class $I I I)$ - includes individuals about one year old,

C - (corresponds to age class IV) - hares over one year old.

5. Method based on the weight of the eye lens. In order to make comparison possible with the methods described above analogical age groups were segregated ( $A, B$ and $C$ ) according to the value of the lens-weight in specimens which were unanimously qualified for the same age groups regardless of the methods used. The divisions into classes established in 
this way were next applied to all the remaining specimens. Use was in addition made of data from the study by $\mathrm{R}$ i e c k (1962).

Identification of age by any of the methods used (except for that of the weight of the eye lens) was carried out independently on the whole of the material.

\section{RESULTS}

Analysis was made of the material, comparing the percentages of agreement between results obtained by the different methods in each age group. The results were compared in four combinations, containing a comparison of each of the 5 analysed methods with the other four (Table 1).

Table 1.

Agreement of identifications of age made by different methods.

\begin{tabular}{|c|c|c|c|c|c|c|c|c|c|c|c|c|c|}
\hline & & \multicolumn{3}{|c|}{$\begin{array}{l}\text { Stroh's metod } \\
\text { (visual) }\end{array}$} & \multicolumn{3}{|c|}{$\begin{array}{l}\text { Ossification of } \\
\text { the skull sutures }\end{array}$} & \multicolumn{3}{|c|}{$\begin{array}{l}\text { Ossification of } \\
\text { the pelvic sutures }\end{array}$} & \multicolumn{3}{|c|}{$\begin{array}{c}\text { Weight of the } \\
\text { eye lens }\end{array}$} \\
\hline & & A & B & C & A & B & $\mathrm{C}$ & A & B & C & A & B & C \\
\hline 을 ฏ & A & $\begin{array}{l}25 \\
49 \%\end{array}$ & 20 & 5 & $\begin{array}{l}20 \\
\mathbf{3 4} \%\end{array}$ & 26 & 4 & $\begin{array}{l}18 \\
\mathbf{3 4} \%\end{array}$ & 28 & 3 & $\begin{array}{l}21 \\
64 \%\end{array}$ & 7 & 2 \\
\hline 范 & B & & $\begin{array}{l}22 \\
31 \%\end{array}$ & 28 & 5 & $\begin{array}{l}25 \\
\mathbf{3 0} \%\end{array}$ & 20 & 3 & $\begin{array}{l}28 \\
\mathbf{3 3} \%\end{array}$ & 17 & 3 & $\begin{array}{l}10 \\
30 \%\end{array}$ & 15 \\
\hline 兵 & C & 1 & 2 & $\begin{array}{l}47 \\
\mathbf{5 7} \%\end{array}$ & & 6 & $\begin{array}{l}44 \\
\mathbf{5 9} \%\end{array}$ & 1 & 8 & $\begin{array}{l}39 \\
\mathbf{5 7} \%\end{array}$ & & & $\begin{array}{l}24 \\
\mathbf{5 8} \%\end{array}$ \\
\hline
\end{tabular}

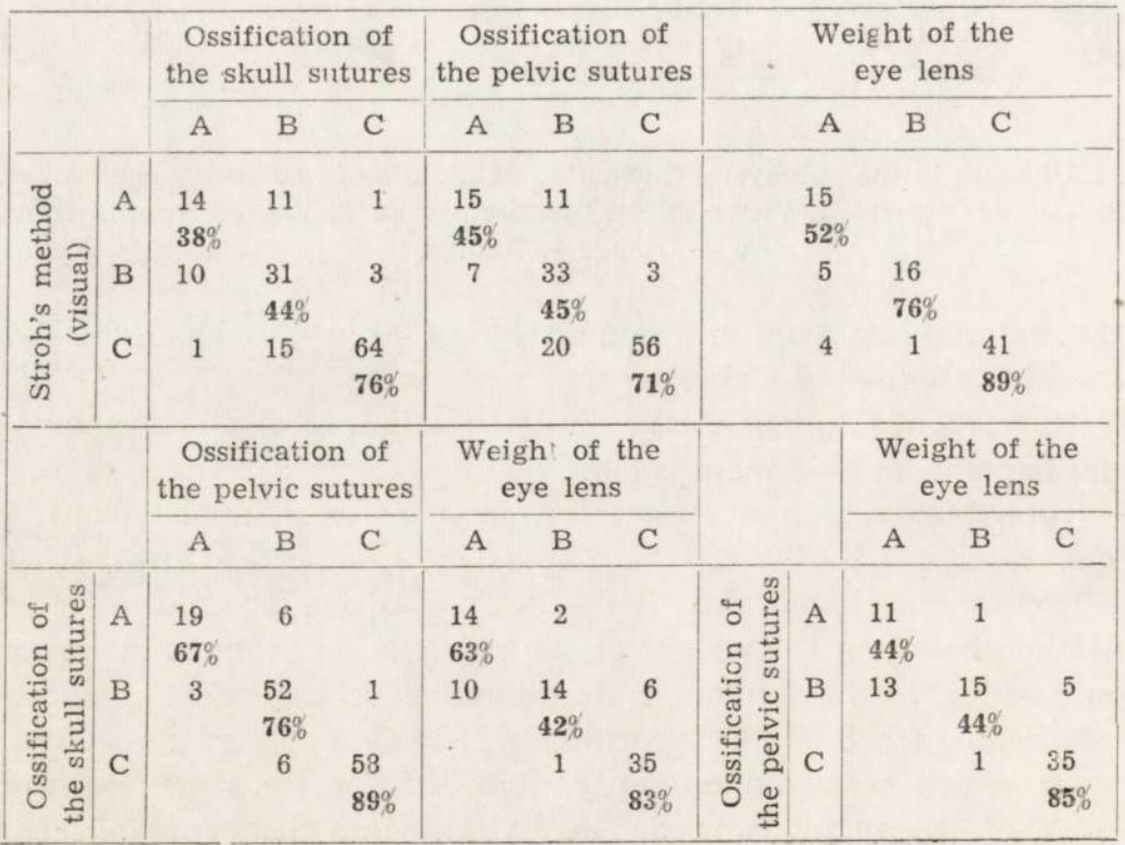


Comparison of identification by Stroh's method, obtained by palpation, reveals the smallest percentages of agreement with the other methods. The relatively greatest degree of agreement occurs in group $C$ $(57-59 \%)$, and the least in group B $(30-33 \%)$. Even the maximum percentages of agreement of this method with others do not, however, in principle go beyond a random distribution. Particularly worthy of emphasis is the fact that divergences exist in definitions of age groups by Stroh's method, i.e. visually and by palpation. These differences are astonishing in view of the fact that both means are based on the variability of the same morphological character. This can be explained only by the assumption that palpation creates the possibility of frequent mistakes being made, as is shown by incorrect classification of specimens by as much as two classes, i.e. individuals with distinct epiphysial thickening were allocated to group $C$ and vice versa. Errors of this kind would seem to be even harder to understand in view of the fact the size of the epi-

Table 2.

Variations in the breadth of the epiphysial thickening of the ulna.

\begin{tabular}{|r|r|r|r|r|r|r|r|r|r|r|r|r|r|r|r|r|}
\hline $\mathrm{mm}$ & 2.80 & 3.15 & 3.50 & 3.85 & 4.20 & 4.55 & 4.90 & 5.25 & 5.60 & 5.95 & 6.30 & 6.65 & 7.00 & 7.35 & $\mathrm{n}$ & $\overline{\mathrm{X}}$ \\
\hline A & & & & & & & 1 & 6 & 2 & 4 & 2 & 5 & 2 & 4 & 26 & 6.18 \\
$B$ & & & 1 & 9 & 6 & 21 & 7 & & & & & & & & 44 & 4.49 \\
$C$ & 3 & 10 & 25 & 39 & 1 & 2 & & & & & & & & & 80 & 3.64 \\
\hline
\end{tabular}

physial thickening is subject to relatively great changes with age. The extent of variation in the breadth of the thickening in group $A$ does not overlap the values of group $C$, while differences in the mean values between groups $B$ and $C$ are also fairly considerable (Table 2).

Comparison of the remaining methods yields different results on account of the fact that definite morphological characters, which alter with age, were compared here. The lack of complete agreement between these methods shows that the growth processes are characterised by difference in the rate at which they take place, but even here it is possible to speak of distinct similarities. The greatest degree of agreement occurs between the identifications made on the skull and pelvis, and between formation of the epiphysial thickening and the weight of the eye lens, the maximum being observed in group $C(89 \%)$. Comparison of results of identifications on the basis of the skull and pelvis exhibit the greatest agreement in all the groups distinguished, forming in addition evidence of the considerable similarity in the course taken by ossification of these parts of the skeleton. 
For practical purposes the division of the hares into two basic age groups is of importance: the group of young hares born the last breeding season, and the group of older animals. On this account analysis was made of results obtained when groups $A$ and $B$ were combined in one class. Treated this way the percentage of agreement of the methods increased considerably and varied from the minimum of $65 \%$ for comparison of identifications made both ways by S t r o h's method to a value of $93 \%$ when comparing identifications on the basis of skull and pelvis. Higher percentages of agreement were obtained in such case for the remaining methods also $(74-88 \%)$, with the exception of the palpation method. The fact must be emphasised that in this case also the agreement of the two ways of defining age by Stro h's method is fortuitous in character, and simultaneously the agreement of results obtained by the palpation technique is the lowest in comparison with all the other methods.

Table 3.

Variations in the weight of the eye lens in age groups.

\begin{tabular}{|r|r|r|r|r|r|r|r|r|r|r|r|r|r|r|}
\hline $\mathrm{mg}$ & 125 & 150 & 175 & 200 & 225 & 250 & 275 & 300 & 325 & 350 & 375 & 400 & $\mathrm{n}$ & $\overline{\mathrm{X}}$ \\
\hline$A$ & 1 & & 3 & 8 & 9 & & 1 & & & & & & 22 & 206.82 \\
$B$ & & & & 1 & 11 & 4 & 1 & & & & & & 17 & 232.35 \\
$\mathrm{C}$ & & & & & & 1 & 6 & 6 & 10 & 11 & 5 & 2 & 41 & 328.66 \\
\hline
\end{tabular}

A relatively high degree of agreement is observed between the weight of the eye lens method and other methods based on growth processes. 'This method might therefore become a good index of the age of hares, if a reliable standard was prepared from marked material, as given by $\mathrm{L}$ o $\mathrm{r} d$ (1959) for Sylvilagus floridanus (A 11 e n, 1890). The distribution of the weight of the lens in age groups for the present material is illustrated by Table 3.

\section{DISCUSSION OF RESULTS}

The results should be treated as pointers only. This results from the fact that all the methods we used are relative methods and do not exactly define the absolute age of the hares.

Among the three methods of defining age based on the ossification process, changes with age in the skull and pelvis were elaborated earlier on the basis of investigations of a large series of hares over the full yearly cycle. The availability of a large amount of material and of information on the specimens examined (date on which they were shot, body weight, state of the gonads, distribution of frequency of age groups in random samples 
over the course of a year) makes the accuracy of two the methods described greater and more even (B u ja ls ka, 1964; C a boń-R a c z y ńska, 1964; R a c z y ń s k i, 1964). The lack of material, the absolute age of which is exactly known, makes it impossible, however, to grasp the scale of individual variation in the ossification process from the age aspect. The degree of correlation of ossification of the skull and pelvis with the disappearance of the epiphysal cartilage on the ulna was also unknown to us. Considerable agreement in distinguishing between age classes on the basis of ossification of the sutures of skull and pelvis, and a slightly lesser degree of agreement in comparing these methods with disappearance of the epiphysial cartilage, suggests that there is some divergence in the ossification process. From the ratio of individuals in group $C$ qualified by $\mathrm{Str}$ oh's method to those identified by means of skull and pelvic differences (respectively $80: 68$ and $76: 59)$ it may be concluded that ossification of the diaphysis takes place slightly earlier than ossification of the skull and pelvic sutures.

The results obtained by the use of S $\mathrm{tr}$ o h's method, i.e. by palpation technique, must be discussed separately. Considerable discrepancies were observed in the series examined in the segregation of different groups by the palpation method in relation to the other methods, and particularly in relation to visual identifications. It is clear from divergences that the stage of disappearance of the thickening (group $B$ ) is the most difficult to identify. Errors are not infrequently made of as much as two age classes (e.g. 5 hares from group $C$ were qualified to group $A$ and vice versa). The cause of this lies in the technique itself used for defining age. It would seem that the possibility of this type of error is dependent on errors committed individually by the person conducting the examination. If in addition we take into account the fact that such classification is frequently carried out in practice under field conditions during examination of mass material, then it is obvious that these circumstances are far from favourable to great accuracy of examination. This method predominates over other possibilities of relatively easy execution of large-scale examinations and is therefore generally used ( $\mathrm{R}$ i e $\mathrm{ck}, 1956$; $\mathrm{S} \mathrm{z}$ e d e r jei e t a 1., 1959; P ielowski, 1962; Hell \& F arka š, 1962 and others). It usually forms the sole source of information as to the increase in young hares and the age structure of the hare populations in shooting areas.

The facts recorded in the present study throw doubt on the value of some results obtained by the palpation technique. It would seem better to base estimates of the degree of ossification of the cartilage on visual observation, in order to exclude the possibility of error. This may be achieved, without unnecessarily complicating the method used, by making a small incision in the skin on the front leg on the outside, i.e. in the place 
in which the thickening occurs, thus laying the bone bare. In order to ensure better observation conditions the skin may be slit round the leg at a distance of about $1 / 3$ of its length from the carpus joint and drawn back to the joint, revealing the final section of the skeleton of the fore arm. The size of the thickening and presence of the cartilage can then be determined without further preparation of muscles. It must be emphasised here that it is easier to observe the occurrence of the epiphysial cartilage on fresh material than on skeletons. The advantage of this technique is the exclusion of error, especially in cases in which the growth process of the long bones is in the final stage, as manifested by the progressive disappearance of the diaphysis, with simultaneous decrease in the epiphysial thickening. The process of ossification of the diaphyses of the long bones, which forms the basis of S troh's method, makes it possible to segregate the young hares in a way to which no objection can be made. It still remains an open question, however, whether it enables all the young hares born the year of examination to be distinguished from the older hares during the hunting period. There are as yet no data in literature as to which month of the hare's life the cartilage disappears completely. R i e c k (1956), taking the scanty data given by A n d e r s e $\mathrm{n}$ (quoted after R i e c k, 1956) and his own material as bases, defines this moment as approximately the eighth month of life. The possibility of individual variability occurring, caused by the different growth rate of the young animals, must, however, be taken into account. This may be influenced by the birth season of the young hares and the tendency connectcd with it to sexual maturescence, the condition of the animals etc., factors connected with the variation in rate and establishment of the moment at which growth is complete. Only large-scale research on marked material can provide an explanation of these problems.

\section{REFERENCES}

i. B u ja $1 \mathrm{ska}$ a, G., 1964: Studies on the European hare. IV. Variations in the pelvis and sacrum. Acta theriol., 9, 18: 287-304.

2. Ca b on - R a c z y ń s ka, K.. 1964: Studies on the European hare. III. Morphological variability of the skull. Acta theriol., 9, 17: 249-285.

3. H e 11, P. \& F a r k a š, L., 1962: Telesná váha a jatočná výtažnost u zajaca polného (Lepus europaeus Pal1.) v obdobi jeho polovníckeho využívania. Sborník VŠP v Nitre: $217-230$.

4. Le chleitner, R. R., 1959: Sex ratio, age classes and reproduction in the black-tailed Jack Rabbit. J. Mamm., 40, 1: 63-81.

5. L or d, R. D., 1959: The lens as an indicator of age in cottontail rabbits. J. Wildl. Mgmt., 23, 3: 358-360.

6. Pielowski, Z., 1962: Uber ökologische Forschungen am Feldhasen in Polen. Beitr. zur Jagd- und Wildforsch., 2: 41-52. Berlin. 
7. R a c zyński. J., 1964: Stuđies on the European hare. V. Reproduction. Acta theriol., 9, 19: 305-352.

8 R i e c k, W., 1956: Untersuchungen über die Vermehrung des Feldhasen. Z. Jagdwiss., 2, 11: 49-90.

9. R i e c k, W., 1962: Analyse von Feldhasenstrecken nach dem Gewicht der Augenlinse. Supp. Ricerche Zoologia Appl. Caccia. 4: 21-29.

1C. Stro h, G., 1931: Zwei sichere Altersmerkmale beim Hasen. Berliner Tierärztliche Wochenschrift. 47, 12: 180-181. Berlin.

11. Szederje i, A., Szeder je i M., \& S tudin ka, L., 1959: Hasen, Rebhühner, Fasanen. Deutscher Bauernverlag: 9-397. Berlin.

Folish Academy of Sciences,

Mammals Research Institute.

Białowieża, woj. Białystok.

Gabriela BUJALSKA, Krystyna CABOÑ-RACZYŃSKA, Jan RACZYŃSKI

SADAN1A NAD ZAJACEM SZARAKIEM. VI. PORÓWNANIE ROŻNYCH METOD OZNACZANIA WIEKU

\section{Streszczenie}

Autorzy porównywali na serii 150 zajęcy, pochodzących z jednego łowiska, zgodność oznaczeń wieku, przeprowadzonych 5 metodami: metoda Stroha w dwóch wariantách: przez obmacywanie przez skórę i wizualnie - przez oglądanie chrząstki epifizalnej; na podstawie kostnienia szwów czaszki i miednicy oraz w oparciu o ciężar soczewki ocznej. Przy użyciu każdej z metod caly material dzielono niezaleźnie na trzy grupy wiekowe $(A, B$ i $C)$.

Stwierdzono najmniejszą zgodność między wynikami metody Stroha uzyskanymi techniką obmacywania i wizualnie (Tabela 1). Wskazuje to na przypadkowy charakter wyników uzyskanych techniką obmacywania. Rozbieżności wyników opartych o kostnienie chrząstki epifizalnej na kości łokciowej oraz kostnienie szwów czaszki i miednicy tlumaczyć można nierównomiernym tempem kostnienia różnych części szkieletu. Dla uniknięcia pomyłek w oznaczaniu wieku metodą Stroha przez obmacywanie autorzy proponują by wiek zajęcy cznaczać w oparciu o obserwację zgrubienia epifizalnego, które jest dobrze wiđoczne na świeżym materiale, po niewielkim nawet rozcięciu skóry. Metoda Stroha, jako nieskomplikowana i szeroko stosowana w masowych badaniach wymaga jednak dokładnego sprawdzenia na licznym mateviale zajẹcy o znanym wieku absolutnym. 